\title{
Optimization of alkaline protease production by Bacillus cereus FT 1 isolated from soil
}

\author{
B. Asha ${ }^{1,2}$, M. Palaniswamy ${ }^{1 *}$ \\ ${ }^{1}$ Karpagam University, Karpagam Academy of Higher Education, Coimbatore, Tamilnadu, India. \\ ${ }^{2}$ SIAS Centre for Scientific Research, Vazhayoor, Malappuram, Kerala, India.
}

\begin{tabular}{|c|c|}
\hline ARTICLE INFO & ABSTRACT \\
\hline Article history: & \multirow{5}{*}{$\begin{array}{l}\text { Alkaline proteases have high commercial value and find multiple applications in various industrial sectors. The present } \\
\text { study intended to isolate a suitable bacterium for alkaline protease production. Protease producing bacteria were } \\
\text { isolated from organic waste containing soil, screened for protease production on skim milk agar plates and confirmed } \\
\text { the protease production through protease assay. The bacterial isolate showing highest alkaline protease production was } \\
\text { selected and identified by microscopic, macroscopic, biochemical and } 16 \mathrm{~S} \text { RNA phylogenetic analyses as Bacillus } \\
\text { cereus FT } 1 \text {. Maximum enzyme production by the isolate was obtained at } 35^{\circ} \mathrm{C} ; \mathrm{pH}, 9.5 ; 2 \% \text { lactose as a carbon source } \\
\text { and } 3.5 \% \text { casein as a nitrogen source after } 48 \mathrm{~h} \text { of incubation. Among the various surfactants tested, tween } 20 \text {, tween } \\
80 \text { and poly ethylene glycol were found to be increasing the protease production by the isolate. } \mathrm{Mn}^{2+} \text {, among the metal } \\
\text { ions tested tremendously increased the protease production. The best organic solvent for protease production was } \\
\text { found to be petrol. With all the optimised cultural conditions, maximum enzyme activity was found to be } 187 \mathrm{U} / \mathrm{mL} \\
\text { and the enzyme was a promising one for detergent industry as an additive enzyme. }\end{array}$} \\
\hline Received on: $23 / 08 / 2017$ & \\
\hline $1 / 2017$ & \\
\hline Available online: $27 / 02 / 2018$ & \\
\hline $\begin{array}{l}\text { Key words: } \\
\text { Alkaline protease, Fermenta- } \\
\text { tion, Protease assay, Bacillus } \\
\text { cereus, Protease production, } \\
\text { Screening, Optimization. }\end{array}$ & \\
\hline
\end{tabular}

\section{INTRODUCTION}

Proteases are enzymes with many physiological roles in all living organisms including cell growth and differentiation (Barrett et al., 2001; Burhan et al., 2003). They are also recognized as industrially important and occupy almost $60 \%$ of the total enzyme market (Gupta et al., 2005; Chu, 2007; Verma et al., 2011). Among the proteases, alkaline proteases have the applications in industries like laundry detergents, pharmaceutical, leather, food processing and proteinaceous waste bioremediation (Bayoudh et al., 2000). They are highly active and stable under alkaline conditions (Maurer, 2004; Saeki et al., 2007).

Proteases produced by bacteria are most significant as their properties can be easily modified through genetic manipulations to suit their various applications (Najafi et al., 2005). Most of the commercially important alkaline proteases are produced by Bacillus spp. The alkaline proteases derived

\section{${ }^{*}$ Corresponding Author}

M. Palaniswamy, Dean, Faculty of Arts, Science and Humanities, Karpagam University, Karpagam Academy of Higher Education, Coimbatore, Tamil Nnadu, India.E-mail:m.palaniswamy@gmail.com from Bacillus sp. are highly active and stable at different $\mathrm{pH}$ and temperature ranges, broad substrate specific, and can be easily purified with low cost (Maurer, 2004; Haddar et al., 2009; Jellouli et al., 2009). Detergent industry requires efficient, environmental friendly and economical strategies for unwanted protein degradation. Alkaline proteases in detergent formulations can act against proteinaceous stains like blood, food and grass stains (Hameed et al., 1996; Smulders et al., 2002; Huang et al., 2003; Wang et al., 2007; Kalpana Devi et al., 2008).

The optimization of different fermentation parameters like nitrogen and carbon source, media $\mathrm{pH}$, incubation temperature, agitation and incubation time can enhance the yield of industrially useful enzymes (Huang et al., 2003; Tobe et al., 2005; Boominadhan et al., 2009; Aruna et al., 2014; Lakshmi et al., 2014). Although, industrially applicable protease enzymes have been identified from different sources, most of them could not resist drastic environmental changes and most of the sources are incapable to produce required quantities to fulfil industrial demands. So, new bacterial strains that can withstand harsh environmental conditions should be isolated for the enhanced production of such enzymes. The present study is aimed at the 
isolation of a proteolytic strain from soil biome and optimization of its cultural conditions for the enhanced enzyme production.

\section{MATERIALS AND METHODS}

\section{Sample collection}

Soil samples contaminated with organic kitchen wastes were collected in sterile glass bottles from five different locations of Vazhayoor Panchayat, Malappuram District, Kerala, India.

\section{Isolation and screening of alkaline protease producing bacteria}

The soil samples were serially diluted using sterile distilled water, spread plated on skim milk agar plates and incubated at $30^{\circ} \mathrm{C}$ for 24 to $48 \mathrm{~h}$ (Anbu et al., 2013). After incubation, the colonies showing clear zones of proteolysis were selected and inoculated to fresh skim milk agar plates by spotting method and incubated for 24 to $48 \mathrm{~h}$ to confirm protease production on the basis of clear zone development. A total of 30 isolates were selected and designated as PS 1 to PS 30. Protease assay was done to find out whether they produce acidic, neutral or alkaline protease (Jani et al., 2016).

\section{Enzyme assay}

The selected isolate was inoculated in $20 \mathrm{ml}$ of protease production media (Composition [g/L]: lactose $10 \mathrm{~g}$; casein $10 \mathrm{~g}$; $\mathrm{KH}_{2} \mathrm{PO}_{4} 2 \mathrm{~g} ; \mathrm{K}_{2} \mathrm{HPO}_{4} 2 \mathrm{~g} ; \mathrm{MgSO}_{4} .7 \mathrm{H}_{2} \mathrm{O} 1 \mathrm{~g}$ ) and incubated for 48 $\mathrm{h}$ on a rotary shaker $(200 \mathrm{rpm})$ at room temperature (Sharma and Aruna, 2012; Saraswathy et al., 2013; Tambekar and Tambekar, 2013). After incubation, the culture media were centrifuged at $5000 \mathrm{rpm}$ for $20 \mathrm{~min}$. at $4^{\circ} \mathrm{C}$ and the cell free supernatants were collected and used as the crude enzyme for protease assay. Protease assay was conducted by a modified method of protease activity assay as described by Cupp-Enyard (2008). Casein dissolved in different $\mathrm{pH}$ buffers [acidic ( $\mathrm{pH}: 4)$, neutral $(\mathrm{pH}: 7)$ and alkaline ( $\mathrm{pH}: 9)$ ] were used as the substrate for the assay. The reaction mixture containing casein and the enzyme solution was incubated for $10 \mathrm{~min}$ at $37^{\circ} \mathrm{C}$, reaction was stopped by adding 3 $\mathrm{ml}$ of $20 \%$ ice cold Tri chloro acetic acid. Precipitated proteins were removed by centrifugation and $0.5 \mathrm{ml}$ of the supernatant was mixed with $2.5 \mathrm{ml}$ of $0.5 \mathrm{M} \mathrm{Na}_{2} \mathrm{CO}_{3}$ and kept for $20 \mathrm{~min}$. at room temperature. Finally, added the appropriately diluted Folin's phenol reagent to the mixture, kept for $10 \mathrm{~min}$. and absorbance was measured at $660 \mathrm{~nm}$ against the blank sample. The amount of enzyme required to liberate $1 \mu \mathrm{g}$ tyrosine per $\mathrm{ml}$ per minute under the standard conditions defined one unit of protease activity (Hameed et al., 1999).

\section{Identification of the isolate}

The bacterial isolate showing maximum alkaline protease activity and maximum proteolytic zone size was selected for further studies. The isolate was identified based on the methods described in Bergey's manual of determinative bacteriology and diagnostic microbiology based on its morphological, cultural and biochemical characteristics (Bergey et al., 1974) and further confirmed based on the $16 \mathrm{~S}$ rRNA sequence analysis and BLAST identification.

\section{Optimization of cultural conditions for protease production}

Different cultural parameters including incubation temperature, broth $\mathrm{pH}$, incubation period, carbon and nitrogen sources and their concentrations were optimised for maximum protease production based on 'One parameter at a time approach'. Protease activity was determined for different ranges of each parameters tested by the above mentioned protease assay procedure using only the alkaline buffer. Optimum temperature for protease production was checked in the range of $10^{\circ} \mathrm{C}$ to $65^{\circ} \mathrm{C}$. Ranges of the broth $\mathrm{pH}$ checked include 3 to 11 . Protease production was determined at various incubation time intervals such as 12, 24, 36, 48, 60 and 72 h. Effect of different carbon sources on protease production was checked by adding $1 \% \mathrm{w} / \mathrm{v}$ of glucose, lactose, fructose, maltose, sucrose, starch, galactose and glycerol. The optimised carbon source was again tested for its optimum concentration in a range of $0.25 \%$ to $4 \%$. Different organic and inorganic nitrogen sources at a concentration of $1 \%$ were checked for maximum protease production including casein, soya bean meal, yeast extract, peptone, beef extract, meat extract, skim milk powder, ammonium acetate, sodium nitrate, ammonium chloride and potassium nitrate. The optimised nitrogen source was again tested for its optimum concentration in a range of $0.25 \%$ to $4 \%$ (Aruna et al., 2014).

Effect of different surfactants like tween 20, tween 80, Poly Ethylene Glycol (PEG), Sodium Dodecyl Sulphate (SDS) and triton $\mathrm{X} 100$ on protease production was studied by incorporating them in to the culture medium and determining protease activity. They were added separately at $0.1 \%$ concentration. Effect of different trace elements or metal ions including barium chloride, copper sulphate, potassium chloride, magnesium chloride, zinc sulphate, ferric chloride, manganese sulphate, mercuric chloride and calcium sulphate were checked by incorporating $0.1 \%$ of each metal ion separately in culture media and protease activity determination. Protease production in presence of organic solvents like petrol, kerosene, methanol, chloroform, hexane and DMSO was also checked by individually adding different solvents at a concentration of $2 \%$ to the culture medium. Protease production media with no added surfactants, metal ions or organic solvents was also kept as control (Ananthan, 2014).

\section{RESULTS AND DISCUSSION}

\section{Isolation and screening of protease producing bacteria}

A total of 30 bacterial isolates showing zone of proteolysis were selected from skim milk agar plates inoculated with the soil sample and all of them were confirmed for protease production on further screening by spotting on skim milk agar plates. The isolates were designated as PS1 to PS30. Colony morphology and Gram stain properties of the 30 isolates were studied. Among the 30 isolates obtained, 15 isolates were showing maximum protease activity in presence of alkaline buffer, and hence were proved to be producing an alkaline protease. The proteolytic zone size of each isolate was measured (Table 1). Figure 1 shows the 15 isolates on skim milk agar plates. Among the rest of the isolates, 8 showed maximum protease activity in presence of acidic buffer and hence were confirmed to be producing acidic protease and 7 showed maximum protease activity in presence of neutral buffer and were confirmed to be producing neutral protease. 


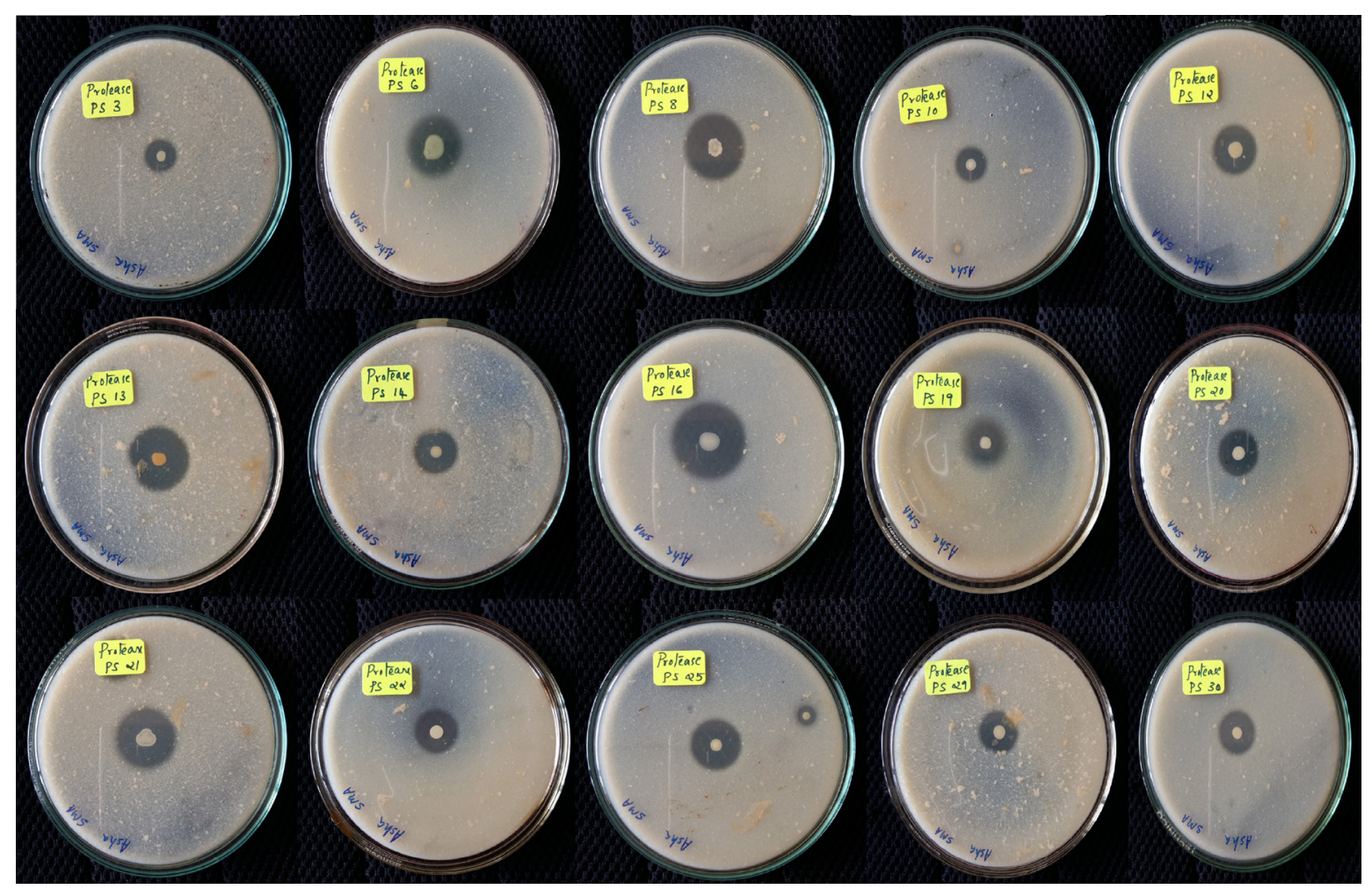

Fig. 1: Alkaline protease producing bacterial isolates on skim milk agar plates showing zone of proteolysis.

The optimum $\mathrm{pH}$ range of alkaline proteases is generally 9 to 11 (Singh et al., 2001; Joshi et al., 2007; Maal et al., 2009), and some of them even showed optimum activity at a range of $\mathrm{pH}$ 11-13 (Takami et al., 1989; Takami et al., 1990; Fujiwara et al., 1993; Gessesse and Gashe, 1997).

Table 1: Proteolytic zone size and protease activity of selected 15 alkaline protease producing bacterial isolates.

\begin{tabular}{lcc}
\hline Bacterial isolate & Zone size of proteolysis $(\mathbf{m m})$ & Protease activity $(\mathbf{U} / \mathbf{m L})$ \\
\hline PS 3 & 10 & 50 \\
PS 6 & 19 & 90 \\
PS 8 & 22 & 127.5 \\
PS 10 & 12 & 50 \\
PS 12 & 17 & 82.5 \\
PS 13 & 23 & 142.5 \\
PS 14 & 15 & 42.5 \\
PS 16 & 26 & 152 \\
PS 19 & 12 & 80 \\
PS 20 & 16 & 107.5 \\
PS 21 & 20 & 100 \\
PS 22 & 15 & 87.5 \\
PS 25 & 17 & 82.5 \\
PS 29 & 16 & 75 \\
PS 30 & 15 & 67.5 \\
\hline
\end{tabular}

"The 15 isolates shown in the table were showing maximum protease activity at alkaline $\mathrm{pH}$ (pH 9).
Among the 15 selected alkaline protease producing isolates, the isolate PS16 showing highest zone size and highest protease activity was selected for further optimization studies.

\section{Identification of the isolate}

The isolate PS 16 formed circular, smooth, opaque and white colonies on nutrient agar (Figure 2). Microscopic studies revealed Gram positive rods (Figure 3) which form endospores. The organism was motile. The isolate PS 16 was identified based on the methods described in Bergey's manual of systematic bacteriology as it belongs to Bacillus sp. depending upon its morphological, cultural and biochemical characteristics. The 16S rRNA gene sequencing of the isolate revealed its identity as Bacillus cereus strain FT1 (Accession number-KP729612.1) when compared with the reference of bacterial species in genomic database banks using the NCBI BLAST.

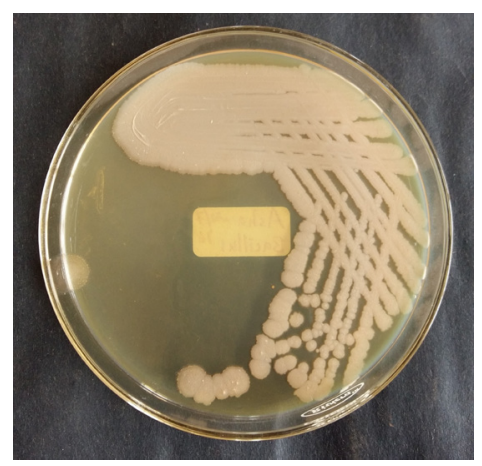

Fig. 2: PS 16 on Nutrient agar. 


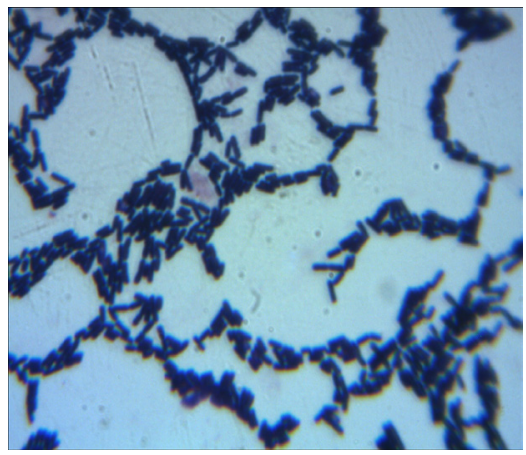

Fig. 3: Gram positive rods of PS 16.

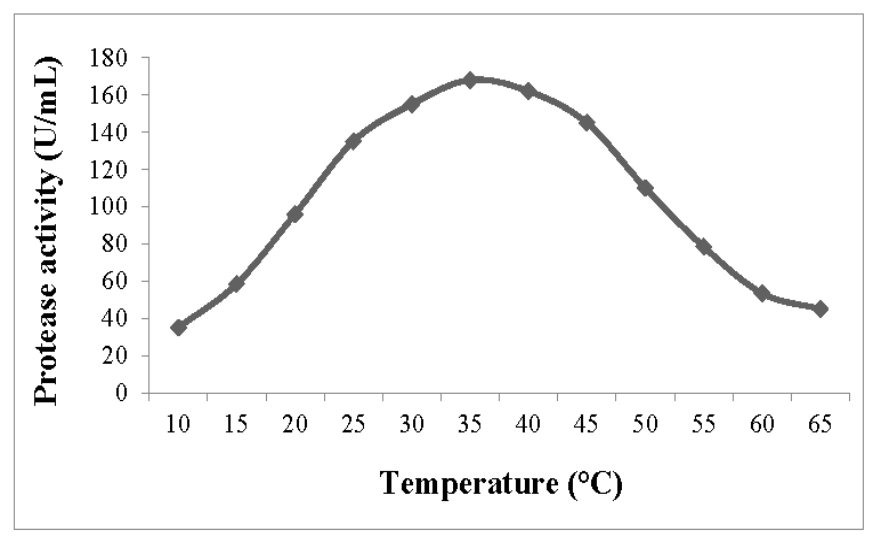

Fig. 4: Effect of temperature on protease production.

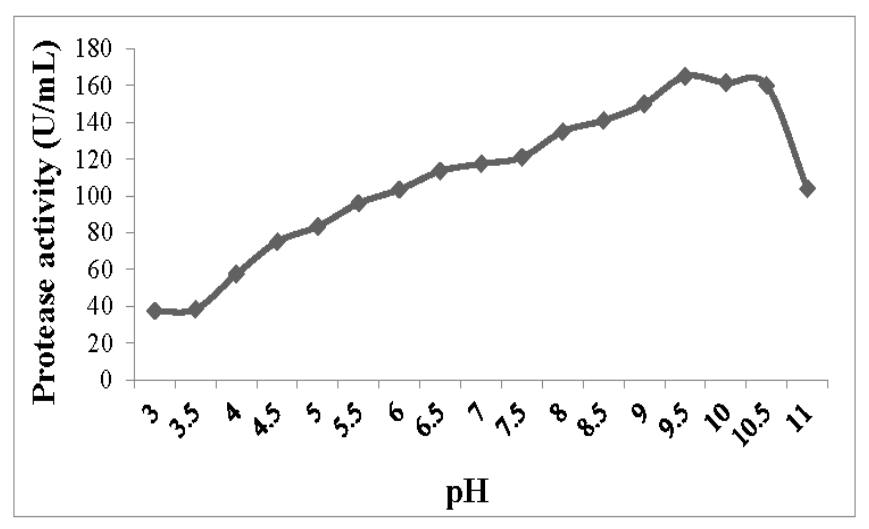

Fig. 5: Effect of $\mathrm{pH}$ on protease production.

Many researchers described Indian soil as a rich source of microorganisms which can produce proteases. Sharma et al., (2014) reported a bacterial strain, Bacillus aryabhatti, isolated from Kurukshetra, Haryana, producing protease enzyme and Kumar et al., (2014) reported two alkaline proteases producing Bacillus strains, Bacillus subtilis EN3 and Bacillus megaterium EN2 isolated from the agricultural soil of C R C Pantnagar. Other proteases producing Bacillus strains were also reported to be isolated from different localities of the country (Asokan and Jayanthi, 2010; Mala and Srividhya, 2010; Naik et al., 2013).
Optimization of cultural conditions for protease production by Bacillus cereus FT 1

\section{Effect of temperature on protease production}

The isolate showed a gradual increase in the protease production up to a temperature of $35^{\circ} \mathrm{C}$ and a gradual decrease thereafter. The highest enzyme production range was between $25^{\circ} \mathrm{C}$ and $45^{\circ} \mathrm{C}$ and the maximum recorded enzyme activity by the isolate was $168 \mathrm{U} / \mathrm{mL}$ when incubated at $35^{\circ} \mathrm{C}$ (Figure 4). At $40^{\circ} \mathrm{C}$ of incubation, $96 \%$ of the enzyme production was maintained and at $45^{\circ} \mathrm{C}$ of incubation, $86 \%$ of enzyme production was maintained. At a temperature of $65^{\circ} \mathrm{C}$, the enzyme production was decreased to $27 \%$. This reveals that the isolate is mesophilic. Studies revealed a link between enzyme synthesis and energy metabolism in bacteria which was controlled by the temperature (Frankena et al., 1986). Similar result of the present study was reported for a Bacillus cereus strain isolated from soil (Ahamed et al., 2016) and for Bacillus licheniformis strain 018 isolated from poultry farm with optimum protease production at $35^{\circ} \mathrm{C}$. Other mesophilic Bacillus strains are also reported with protease production by Dorcas and Pindi (2016) and Kalpana et al., (2016).

\section{Effect of pH on protease production}

The enzymatic processes and nutrient transport across the cell membrane were strongly affected by the culture $\mathrm{pH}$ (Moon and Parulekar, 1991). Bacillus cereus FT 1 was producing considerable amount of protease enzyme at a $\mathrm{pH}$ range of 7.5 to 10.5 (Figure 5). The maximum enzyme production occurred at $\mathrm{pH} 9.5$ with a protease activity of $165 \mathrm{U} / \mathrm{mL}$, indicating the alkaliphilic nature of the isolate. An alkaline $\mathrm{pH}$ of the medium must be maintained for maximum protease yield from alkaliphiles (Aunstrup, 1980). Kumar et al., (1999), Pastor et al., (2001) and Khusro, (2015) demonstrated the alkaline pH optima of Bacillus sp. for protease production. Olajuyigbe and Ehiosun, (2013) and Sharmin et al., (2005) reported maximum protease yield by Bacillus coagulans PSB-07 and Bacillus amovivorus at $\mathrm{pH} 8$ and 8.5, respectively. A maximum yield of protease at $\mathrm{pH} 9$ was reported by some strains of Bacilli such as Bacillus proteolyticus CFR3001, by Bhaskar et al., (2007), Bacillus cereus by Uyar et al., (2011) and Bacillus flexus by Verma et al., (2013).

\section{Effect of incubation period on protease production}

The isolate showed protease production in considerable amount at $48 \mathrm{~h}$ of incubation (Figure 6). Protease activity at $48 \mathrm{~h}$ was $148 \mathrm{U} / \mathrm{mL}$. At 60 and $72 \mathrm{~h}$ of incubation, $89 \%$ and $82 \%$ of protease activity was maintained respectively. Similar results were reported by many scientists. Hoshino et al., (1995) and Shumi et al., (2004) reported maximum protease production by bacteria at 48 to $72 \mathrm{~h}$. Aruna et al., (2014) isolated Bacillus tequilensis strain SCSGAB0139 with optimum incubation period of $48 \mathrm{~h}$ for maximum protease production. Optimisation studies of Bacillus coagulans PSB-07 by Olajuyigbe and Ehiosun (2013), Bacillus pumilus D-6 by Bajaj and Jamwal (2013) and Bacillus firmus by Vadlamani and Parcha (2012) also reported a $48 \mathrm{~h}$ of optimum incubation period for maximum protease production. 


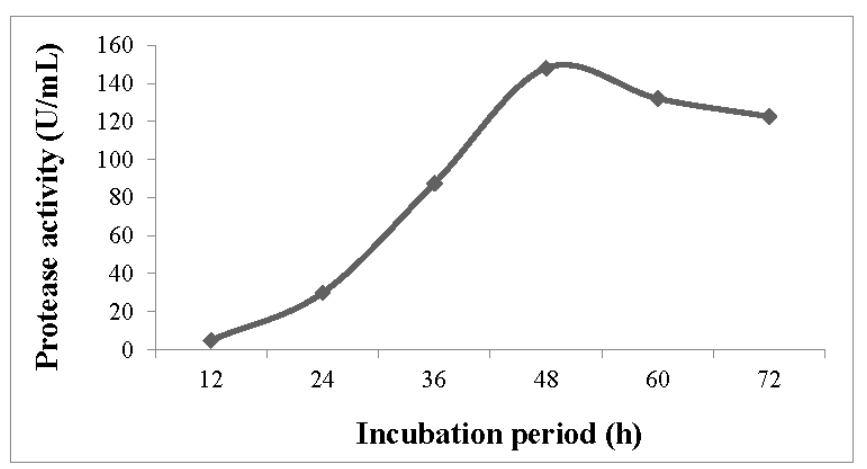

Fig. 6: Effect of incubation period on Protease production.

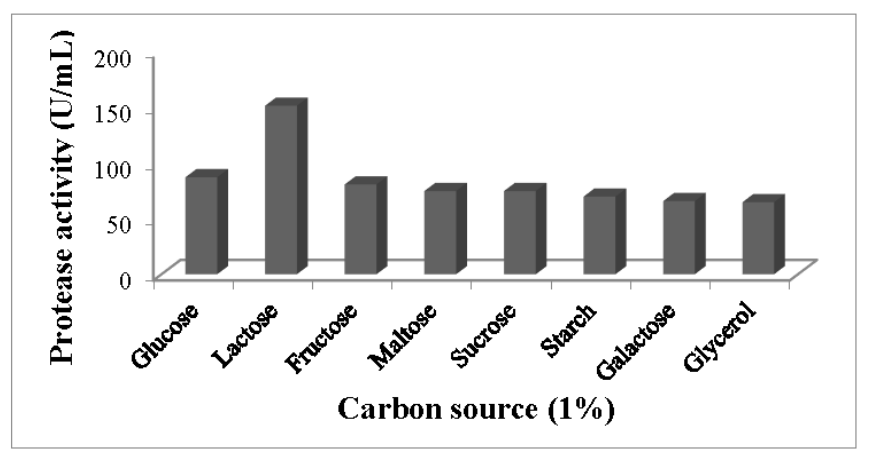

Fig. 7: Effect of carbon source on protease production.

The synthesis of protease enzyme in Bacillus species was controlled by mechanisms operative during the transition state between exponential and the stationary growth phases (Priest, 1977; Strauch and Hoch, 1993). It occurred while the culture was metabolically active (Kanchana and Padmavathy, 2010). However, Gupta et al., (2002) reported the extracellular protease production as a manifestation of nutrient scarcity in the beginning of stationary phase. According to Ward (1995), more protease production by Bacillus sp. occurred during late exponential phase and was correlated with the high rate of protein turnover during endospores formation.

\section{Effect of carbon source on protease production}

Among the various carbon sources (1\%) tested, lactose was found to be highly influencing the enzyme production with a protease activity of $151 \mathrm{U} / \mathrm{mL}$ whereas, all the other sources used resulted in only $50 \%$ enzyme yielding when compared to lactose (Figure 7). Concentration of lactose in the production medium was also optimised by conducting experiments with increasing the concentrations of lactose in the medium (Figure 8). The maximum protease activity was found to be $161 \mathrm{U} / \mathrm{mL}$ at $2 \%$ lactose and the minimum protease activity was $85 \mathrm{U} / \mathrm{mL}$ at $0.25 \%$ lactose. Above $2 \%$ lactose, protease production decreased slightly and at $4 \%$, the activity was reduced to $87 \%$ of the maximum activity. Carbon source influenced the protease production considerably and different bacteria utilized different carbon source for their growth and metabolism. Tambekar and Tambekar, (2013) reported a halophilic bacterium, Bacillus odysseyi, which utilized lactose as a carbon source for maximum protease production compared to fructose, maltose or starch. A strain of Vibrio GA CAS2, as reported by Ananthan (2014) utilized lactose as the suitable carbon source for maximum protease production. Other important carbon sources for protease production as reported by previous studies included glucose (Badhe et al., 2016; Dorcas and Pindi, 2016), maltose (Saraswathy et al., 2013; Vanitha et al., 2014) and galactose (Pant et al., 2015).

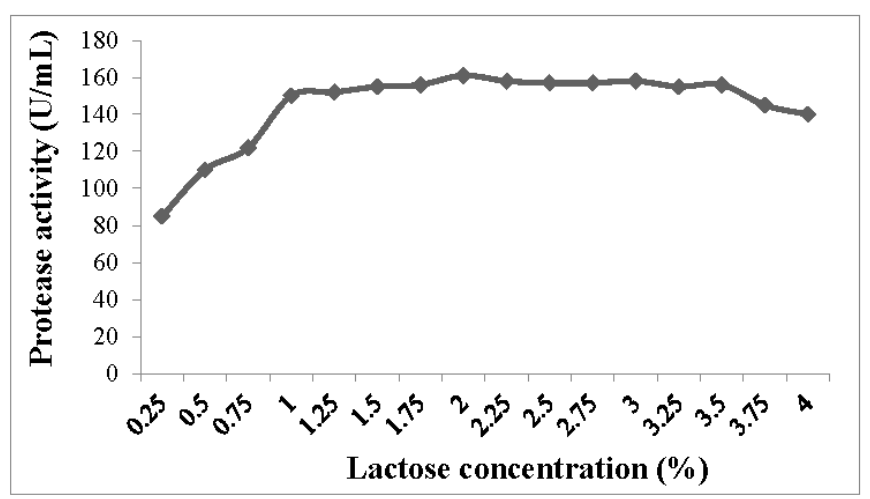

Fig. 8: Effect of lactose concentration on protease production.

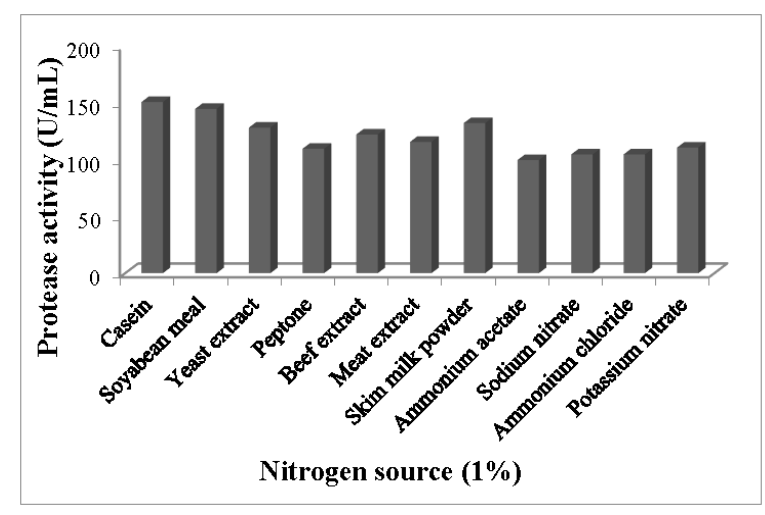

Fig. 9: Effect of nitrogen source on protease production.

\section{Effect of nitrogen source on protease production}

Casein was found to be the best nitrogen source by the present isolate to produce maximum protease enzyme compared to other organic and inorganic nitrogen sources (1\%) tested. A protease activity of $151 \mathrm{U} / \mathrm{mL}$ was obtained when the media was supplied with casein as the nitrogen source (Figure 9). Concentration of casein in the production medium was also optimised by conducting experiments with increasing concentrations of the casein in the medium. The maximum protease activity was found to be 182.5 $\mathrm{U} / \mathrm{mL}$ at $3.5 \%$ casein and the minimum protease activity was $128.5 \mathrm{U} / \mathrm{mL}$ at $0.25 \%$ casein (Figure 10 ).

Enzyme production was influenced by nitrogen source (Ward, 1995; Mehta et al., 2006) and different bacterial strains utilize different substrates as nitrogen sources for effective protease production (Gupta and Khare, 2007). Casein was reported as a major nitrogen source for many microorganisms for maximum protease production. Jayasree et 
al., (2009) reported 1\% casein as the main source of nitrogen for alkaline protease production by Streptomyces pulveraceus. Streptomyces halstedii Salh-12 and Streptomyces endus Salh40, two most potent proteolytic halotolerant thermophilic and mesophilic organisms respectively utilized $1 \%$ casein as a major nitrogen source in protease production medium as reported by El Zawahry et al. (2007). Many other organic and inorganic nitrogen sources were also found to be enhancing the production of the protease enzyme. In the present study, when yeast extract was used as a nitrogen source, it showed $85 \%$ protease production compared to casein. In many studies, yeast extract results in higher protease production than casein (Vanitha et al., 2014; Badhe et al., 2016; Khusru, 2016).

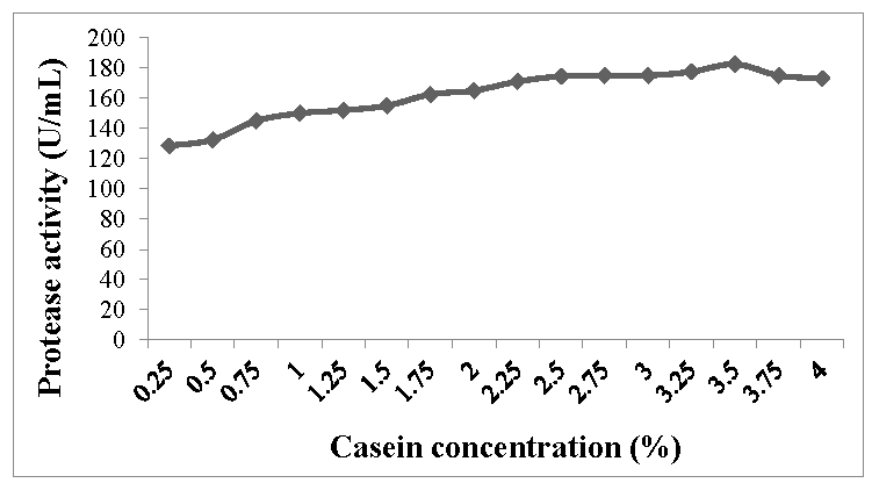

Fig. 10: Effect of casein concentration on protease production.

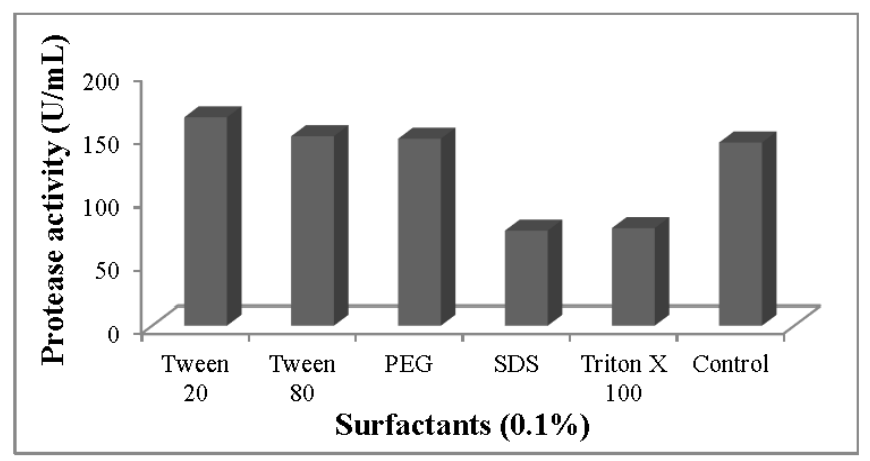

Fig. 11: Effect of surfactants on protease production.

With all the optimized cultural conditions like incubation period, temperature, $\mathrm{pH}$ and concentration of nitrogen and carbon sources, the protease enzyme produced by Bacillus cereus FT1 showed an enzyme activity of $187 \mathrm{U} / \mathrm{mL}$.

\section{Effect of surfactants on protease production}

Protease production by Bacillus cereus FT 1 was higher with surfactants tween $20(165 \mathrm{U} / \mathrm{mL})$, tween $80(150 \mathrm{U} / \mathrm{mL})$ and poly ethylene glycol $(148 \mathrm{U} / \mathrm{mL})$ than the control $(145 \mathrm{U} /$ $\mathrm{mL})$. Protease production was less in the presence of SDS (75 U/ $\mathrm{mL}$ ) and triton X $100(77 \mathrm{U} / \mathrm{mL})$ (Figure 11). Surfactants were reported to be encouraging the extra cellular enzyme production by bacteria including Bacillus sp. (Reddy et al., 1999; Nascimento and Martins, 2006). Esakkiraj et al., (2011) reported increased protease production by Serratia proteamaculans in presence of triton X 100 and tween 80 and Ananthan, (2014), reported an increased protease production in the presence of tween 80 by a Vibrio sp. isolated from the ascidian, Polyclinum glabrum.

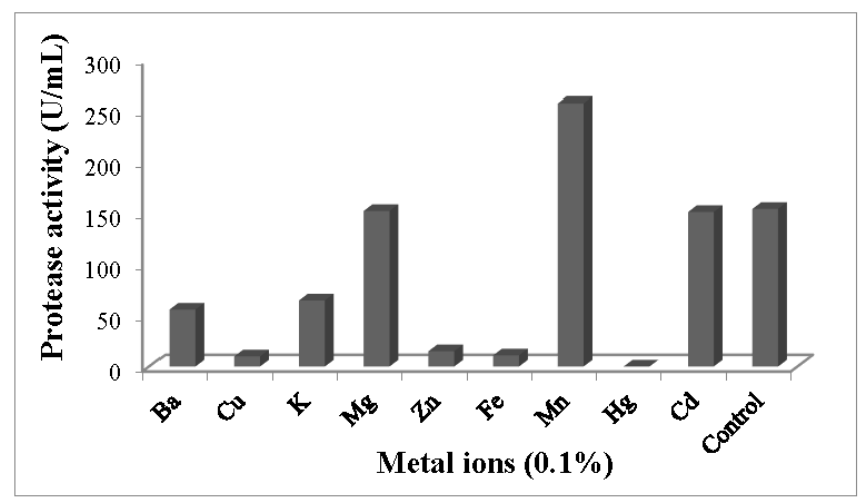

Fig. 12: Effect of metal ions on protease production.

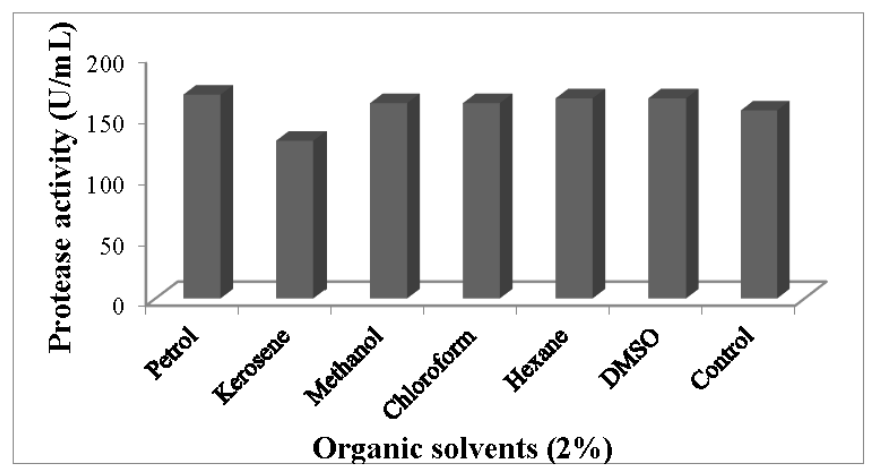

Fig. 13: Effect of organic solvents in protease production.

\section{Effect of metal ions on protease production}

The highest level of protease production was observed in the presence of $\mathrm{Mn}^{2+}$ for the isolate $(258 \mathrm{U} / \mathrm{mL})$ (Figure 12), which was far higher than the control value $(155 \mathrm{U} / \mathrm{mL}) . \mathrm{Mg}^{2+}$ and $\mathrm{Cd}^{2+}$ did not affect the enzyme production much and the other metal ions tested resulted in a decrease in protease production with a complete absence of it in the presence of $\mathrm{Hg}^{2+}$. The results suggested that the isolate required appropriate metal ion for protease production. Tambekar and Tambekar, (2013) worked on three Bacillus species, Bacillus pseudofirmus, Cohnella thermotolerans and Bacillus odyssey reported the effect of $\mathrm{Mg}^{2+}$, $\mathrm{Ca}^{2+}, \mathrm{Cu}^{2+}$ and $\mathrm{Mn}^{2+}$ on improving the protease production by the isolates.

\section{Effect of organic solvents on protease production}

Six different organic solvents were screened for protease production in the present study. Among which, five of them expressed maximum protease production compared to the control. Petrol showed maximum protease production (168 U/ $\mathrm{mL})$ followed by hexane and DMSO $(165 \mathrm{U} / \mathrm{mL})$ and methanol and chloroform (161 U/mL) (Figure 13). Kerosene decreased protease production compared to the control. The ability of 
microorganisms to tolerate organic solvents determines their protease production capacity (Ananthan, 2014). Many bacterial species have reported to be influenced by organic solvents in their extracellular enzyme production. Bacillus sphaericus DS11 showed enhanced production of protease enzyme with an activity of $1182.68 \mathrm{U} / \mathrm{mL}$ in the presence of optimised concentrations of glycerol (Liu et al., 2010) and Vibrio sp. GA CAS2 showed a highest protease production $(808.69 \mathrm{U} / \mathrm{mL})$ in the presence of chloroform (Ananthan, 2014).

\section{CONCLUSION}

Alkaline proteases have many applications in different industries and environmental bioremediations. Maximum enzyme production is aimed while selecting an organism for the enzyme production for commercial uses. The present study reported the increased alkaline protease production by the soil isolated Bacillus cereus FT 1 under optimised cultural conditions. The enzyme production by the isolate was even more enhanced in the presence of surfactants, metal ions and organic solvents. The results suggest the industrial usefulness of bacterial isolate and further studies are in progress in order to purify and characterize the enzyme for commercial applications.

\section{REFERENCES}

Ahamed M, Rehman R, Siddique A, Hasan F, Ali N, Hameed A. Production, purification and characterization of detergent-stable, halotolerant alkaline protease for eco-friendly application in detergents' industry. Int $\mathrm{J}$ Biosci, 2016; 8: 47-65.

Ananthan G. Optimization of novel protease production through submerged fermentation by Ascidian associated Vibrio sp., GA CAS2. World J Pharma Pharma Sci, 2014; 3: 756-770.

Aruna K, Shah J, Birmole R. Production and partial characterization of alkaline protease from Bacillus tequilensis strains CSGAB0139 isolated from spoilt cottage cheese. Int J Appl Biol Pharma Tech, 2014; 5: 201-221.

Asokan S, Jayanthi C. Alkaline protease production by Bacillus licheniformis and Bacillus coagulans. J Cell Tissue Res, 2010; 10: 21192123.

Aunstrup K. 1980. Proteinases In: Rose AH, ed. Economic Microbiology: Microbial Enzymes and Bioconversions. New York: Academic Press 5: 50-114.

Badhe P, Joshi M, Adivarekar R. Optimized production of extra cellular proteases by Bacillus subtilis from degraded abattoir waste. J BioSci Biotechnol, 2016; 5: 29-36.

Bajaj BK, Jamwal G. Thermostable alkaline protease production from Bacillus pumilus D-6 by using agro-residues as substrates. Adv Enzyme Res, 2013; 1:30-36.

Barrett AJ, Rawlings ND, O'Brien EA. The MEROPS database as a protease information system. J struct boil, 2001; 134(2-3):95-102.

Bayoudh A, Gharsallah N, Chamkha M, Dhouib A, Ammar S, Nasri M. Purification and characterization of an alkaline protease from Pseudomonas aeruginosa MN1. J Ind Microbiol Biotechnol, 2000; 24:291295.

Bergey DH, Buchanan RE, Gibbons NE. 1974. Bergey's Manual of Determinative Bacteriology, 8th edition. The Williams and Wilkins Co., Baltimore, USA: 15-36.

Bhaskar N, Sudeepa ES, Rashmi HN, Tamil Selvi A. Partial purification and characterization of protease of Bacillus proteolyticus CFR3001 isolated from fish processing waste and its antibacterial activities. Bioresour Technol, 2007; 98:2758-2764.

Boominadhan U, Rajkumar R, Sivakumaar PKV, Joe MM. Optimization of protease enzyme production using Bacillus Sp. isolated from different wastes. Bot Res Int, 2009; 2:83-87.
Burhan A, Nisa U, Gokhan C, Omer C, Ashabil A, Osman G. Enzymatic properties of a novel thermostable, thermophilic, alkaline and chelator resistant amylase from an alkaliphilic Bacillus sp. isolate ANT-6. Process Biochem, 2003; 38:1397-1403.

Chu W H. Optimization of extracellular alkaline protease production from species of Bacillus. J ind microbial Biotechnol, 2007; 34:241-245.

Cupp-Enyard C. Sigma's non-specific protease activity assayCasein as substrate. J Vis Exp, 2008; 19:899.

Dorcas K, Pindi PK. Optimization of protease production from Bacillus cereus. Int J Curr Microbiol Appl Sci, 2016; 5:470-478.

El Zawahry YA, Awny M, Tohamy EY, Abou Zeid AAM, Reda FM. Optimization, characterization and purification of protease production by some Actinomycetes isolated under stress conditions. Proceeding Of The Second Scientific Environmental Conffer, Zagazig Uni, 2007; 153-175.

Esakkiraj P, Sankaralingam S, Usha R, Palavesam A, Immanuel G. Solid-state protease production using anchovy waste meal by moderate halophile Serratia proteamaculans AP-CMST isolated from fish intestine. Ann Microbiol, 2011; 61:749-755.

Frankena J, Koningstein GM, Van Verseveld HW, Stouthamer AH. Effect of different limitations in chemostat cultures on growth and production of exocellular protease by Bacillus licheniformis. Appl Microbiol Biotechnol, 1986; 24:106-12.

Fujiwara N, Masui A, Imanaka T. Purification and properties of the highly thermostable alkaline protease from an alkalophilic and thermophilic Bacillus sp. J Biotechnol, 1993; 30:245-256.

Gessesse A, Gashe BA. Production of alkaline protease by alkaliphilic bacteria isolated from an alkaline soda lake. Biotechnol Lett, 1997; 19:479-481.

Gupta A, Khare SK. Enhanced production and characterization of a solvent stable protease from solvent tolerant Pseudomonas aeruginosa PseA. Enzyme Microb Technol, 2007; 42:11-16.

Gupta A, Roy I, Patel RK, Singh SP, Khare SK, Gupta MN. One-step purification and characterization of an alkaline protease from halo alkaliphilic Bacillus sp. J Chromatogr A, 2005; 1075:103-108.

Gupta R, Beg QK, Lorenz P. Bacterial alkaline proteases: Molecular approaches and industrial applications. Appl Microbiol Biotechnol, 2002; 59:15-32.

Haddar A, Agrebi R, Bougatef A, Hmidet N, Sellami-Kamoun A, Nasri M. Two detergent stable alkaline serine proteases from Bacillus mojavensis A21: purification, characterization and potential application as a laundry detergent additive, Bioresour Technol, 2009; 100:3366-3373.

Hameed A, Keshavarz T, Evans CS. Effect of dissolved oxygen tension and $\mathrm{pH}$ on the production of extra cellular protease from a new isolate of Bacillus subtilis $\mathrm{K} 2$, for use in leather processing. J ChemTechnol Biotechnol, 1999; 74:5-8.

Hameed A, Natt MA, Evans CS. Production of alkaline protease by a new Bacillus subtilis isolate for use as a bating enzyme in leather treatment. World J Microbiol Biotechnol, 1996; 12:289-291.

Hoshino E, Maruta K, Wada Y, Mori K. Hydrolysis of human horny cells by alkaline protease: morphological observation of the process. J Am Oil Chem Soc, 1995; 72:785-79.

Huang Q, Peng Y, Li X, Wang H, Zhang Y. Purification and characterization of an extracellular alkaline serine protease with dehairing function from Bacillus pumilus. Cur microbiol, 2003; 46:169-173.

Jani SA, Parekh YM, Parmar TN, Dalwadi TJ, Patel HB, Parmar SK. Screening and characterization of alkaline protease producing Bacillus strain B-4 Bacillus flexus and study of its potential for alkaline protease production. Int J Curr Microbiol Appl Sci, 2016; 5:767-787.

Jayasree D, Sandhya Kumari TD, Kavi Kishor PB, Vijayalakshmi M, Lakshmi Narasu M. Optimization of production protocol of alkaline protease by Streptomyces pulvereceus. Inter JRI Sci Technol, 2009; 1(2):7982.

Jellouli K, Bougatef A, Manni L, Agrebi R., Siala R, Younes I, Nasri M. Molecular and biochemical characterization of an extracellular serine-protease from Vibrio metschnikovii J1. J Ind Microbiol Biotechnol, 
2009; 36:939-948.

Joshi SG, Tejashwini MM, Revati N, Sridevi R, Roma D. Isolation, identification and characterization of a feather degrading bacterium. Int J Poult Sci, 2007; 6:689-693.

Kalpana Devi M, Rasheedha Banu A, Gnanaprabhai GR, Pradeep BV, Palaniswamy M. Purification, characterization of alkaline protease enzyme from native isolate Aspergillus niger and its compatibility with commercial detergents. Ind J Sci Technol, 2008; 1:1-6.

Kalpana VN, Sravani N, Vigneshwari T, Devi Rajeshwari V. An inexpensive substrate for the production of alkaline protease by Bacillus sp and its application studies of Manihot esculenta. Der Pharmacia Lettre, 2016; 8:220-232.

Kanchana M, S Padmavathy. Optimization of extracellular alkaline protease enzyme from Bacillus sp. The Bioscan, 2010; 5:85-87.

Khusro A. Statistical approach for optimization of independent variables on alkali-thermo stable protease production from Bacillus licheniformis strain BIHPUR 0104. Electron J Biol, 2015; 11:93-97.

Kumar CG, Tiwari MP, Jany KD. Novel alkaline serine proteases from alkalophilic Bacillus spp.: purification and some properties. Process Biochem, 1999; 34(5):441-449.

Kumar D, Kumar V, Verma AK, Singh P, Dubey A. Characterization and immobilization of partially purified alkaline protease extracted from rhizospheric soil bacterium, Bacillus megaterium strain EN-2 and Bacillus subtilis strain EN-3. Afr J Microbiol res, 2014; 8:33-39.

Lakshmi BKM, Ratnasri PV, AmbikaDevi K, Hemalatha KPJ. Screening, optimization of production and partial characterization of alkaline protease from haloalkaliphilic Bacillus sp. J Res Eng Technol, 2014; 3:435443.

Liu S, Fang Y, Lv M, Wang S, Chen L. Optimization of the production of organic solvent-stable protease by Bacillus sphaericus DS11 with response surface methodology. Bioresour Technol, 2010; 101:79247929.

Maal KB, Emtiazi G, Nahvi I. Production of alkaline protease by Bacillus cereus and Bacillus polymixa in new industrial culture mediums and its immobilization. Afr J Microbiol Res, 2009; 3:491-497.

Mala M, Srividya S. Partial purification and properties of a laundry detergent compatible alkaline protease from a newly isolated Bacillus species Y. Ind J Microbiol, 2010; 50:309-317.

Maurer KH. Detergent proteases. Curr opin Biotechnol, 2004; 15(4):330-334.

Mehta VJ, Thumar JT, Singh SP. Production of alkaline protease from alkaliphytic actinomycete. Bioresour Technol, 2006; 97:1650-1654.

Moon SH, Parulekar SJ. A parametric study of protease production in batch and fed-batch cultures of Bacillus firmus. Biotechnol Bioeng, 1991; 37:467-83.

Naik LS, Aruna K, Sreevennela P, Ramana Devi V. Isolation and biochemical characterization of protease isolated from Bacillus sp. SVN12L. Int J Res Pure Appl Microbiol, 2013; 3:94-101.

Najafi MF, Deobagkar D, Deobagkar D. Potential application of protease isolated from Pseudomonas aeruginosa PD100. Electron J Biotechnol, 2005; 8:197-203.

Nascimento WCA, Martins MLL. Studies on the stability of protease from Bacillus $\mathrm{sp}$. and its compatibility with commercial detergent. Braz J Microbiol, 2006; 37:307-311.

Olajuyigbe FM, Ehiosun KI. Production of thermostable and organic solvent-tolerant alkaline protease from Bacillus coagulans PSB-07 under different submerged fermentation conditions. Afr J Biotechnol, 2013; 12:3341-3350.

Pant G, Prakash A, Pavani JVP, Bera S, Deviram GVNS, Kumar A, Panchpuri M, Prasuna RG. Production, optimization and partial purification of protease from Bacillus subtilis. J Taibah Univ Sci, 2015; 9:50-55.

Pastor MD, Lorda GS, Balatti A. Proteases obtention using Bacillus subtilis- 3411 and amaranth seed meal medium at different aeration rate. Braz J Microbiol, 2001; 32(1):6-9.
Priest FG. Extracellular enzyme synthesis in the genus Bacillus. Bacteriol Rev, 1977; 41:711-753.

Reddy RM, Reddy PG, Seenayya G. Enhanced production of thermostable $\beta$-amylase and pullanase in the presence of surfactants by Clostridium thermosulfurogenes SV2. Process Biochem, 1999; 34:87-92.

Saeki K, Ozaki K, Kobayashi T, Ito S. Detergent alkaline proteases: enzymatic properties, genes, and crystal structures. J Biosci Bioeng, 2007; 103:501-508.

Saraswathy N, Yeole GS, Parikh AJ, Meena C. Production and optimization of protease from Bacillus licheniformis NCIM 2044. Asian J Pharma Life Sci, 2013; 3:9-15.

Sharma KM, Kumar R, Vats S, Gupta A. Production, partial purification and characterization of alkaline protease from Bacillus aryabhattai K3. Int J Adv Pharma Biol Chem, 2014; 3:290-298.

Sharmin S, Hossain MT, Anwar MN. Isolation and characterization of a protease producing bacteria Bacillus amovivorus and optimization of some factors of culture condition for protease production. $\mathrm{J}$ Biol Sci, 2005; 5:358-362.

Shumi W, Hossain MT, Anwar MN. Proteolytic activity of a bacterial isolate Bacillus fastidious den Dooren de Jong. J Biol Sci, 2004; $4: 370-374$.

Singh J, Vohra RM, Sahoo DK. Purification and characterization of two extracellular alkaline proteases from a newly isolated obligate alkaliphilic Bacillus sphaericus. J Ind Microbiol Biotechnol, 2001; 26:387393.

Smulders E, Rahse W, Von Rybinski W, Steber J, Sung E, Wiebel F. 2002. Detergent Ingredients. In: Smulders, E. ed. Laundry detergent. Wiley-VCH, Verlag GmbH \& Co. 38-98.

Strauch MA, Hoch JA. Transition-state regulators: sentinels of Bacillus subtilis post-exponential phase gene expression. Mol Microbiol, 1993; 7:337-342.

Takami H, Akiba K, Horikoshi K. Characterization of an alkaline protease from Bacillus sp. no. AH-101. Appl Microbiol Biotechnol, 1990; 33:519-523

Takami H, Akiba T, Horikoshi K. Production of extremely thermostable alkaline protease from Bacillus sp. no. AH-101. Appl Microbiol Biotechnol, 1989; 30(2):120-124.

Tambekar S D, Tambekar D H. Optimization of the production and partial characterization of an extracellular alkaline protease from thermo-halo-alkalophilic lonar lake bacteria. Biosci Discov, 2013; 4:30-38.

Tobe S, Nagoh Y, Watanabe T, Mukaiyama T. Bacteriolytic activity of detergent protease and its enhancement by detergents materials. J Oleo Sci, 2005; 54:389-395.

Uyar F, Porsuk I, Kizil G, Ince E. Optimal conditions for production of extracellular protease from newly isolated Bacillus cereus strain CA15. EurAsian J BioSci, 2011; 5:1-9.

Vadlamani S, Parcha SR. Optimization of alkaline protease production from locally isolated Bacillus sp. Bacillus firmus from soil microorganisms in batch culture using statistical design. Int J Eng Res Appl, 2012; 2:917-924.

Vanitha N, Rajan S, Murugesan AG. Optimization and production of alkaline protease enzyme from Bacillus subtilis 168 isolated from food industry waste. Int J Cur Microbiol Appl Sci, 2014; 3:36-44.

Verma J, Saxena S, Shikha. 16S rDNA Based Identification of alkaline protease producing alkaliphilic Bacillus $\mathrm{Sp}$. isolated from dairy industry soil and evaluation of the enzyme potential in detergent formulation. Res J Pharma Bio Chem Sci, 2013; 4:1339-1349.

Verma OP, Kumari P, Shukla S, Singh A. Production of Alkaline Protease by Bacillus subtilis (MTCC7312) using Submerged Fermentation and Optimization of Process Parameters. Euro J Exp Bio, $2011 ; 1: 124-129$.

Wang HY, Liu DM, Liu Y, Cheng CF, Ma QY, Huang Q, Zhang YZ. Screening and mutagenesis of a novel Bacillus pumilus strain producing alkaline protease for dehairing. Lett in appl microbiol, 2007; $44: 1-6$. 
Ward OP. 1995. Proteolytic enzymes. In M Moo-Young ed. Comprehensive Biotechnology. 3:789-818.

How to cite this article:

Asha B, Palaniswamy M. Optimization of alkaline protease production by Bacillus cereus FT 1 isolated from soil. J App Pharm Sci, 2018; 8(02): 119-127. 